\title{
PENGEMBANGAN MEDIA PEMBELAJARAN VCD TENIS LAPANGAN BAGI SISWA SEKOLAH DASAR
}

\author{
THE DEVELOPMENT OF INSTRUCTIONAL MEDIA VCD \\ IN TENNIS BALL GAMES FOR ELEMENTARY SCHOOL STUDENTS
}

\author{
Danang Kusumawardana, Sukadiyanto \\ SMAN 1 Grabag Kabupaten Magelang, Universitas Negeri Yogyakarta \\ danang_ksm66@yahoo.com, sukadiyanto_fik@yahoo.com
}

\begin{abstract}
Abstrak
Penelitian ini bertujuan untuk mengembangkan media pembelajaran tenis lapangan pada siswa sekolah dasar kelas atas dan dapat membantu mengatasi masalah keterbatasan sumber belajar di lingkungan sekolah dasar khususnya materi permainan bola kecil cabang tenis lapangan. Subjek penelitian ini adalah siswa sekolah dasar kelas atas $(4,5$ dan 6$)$. Penelitian ini menggunakan desain penelitian dan pengembangan. Pengembangan dilakukan dalam beberapa langkah, yaitu: (1) studi pendahuluan, (2) proses pengembangan, (3) uji lapangan. Instrumen yang digunakan dalam penelitian ini adalah lembar evaluasi. Hasil penelitian menunjukkan bahwa semua aspek dalam media pembelajaran yang dikembangkan sangat baik. Penilaian ini dilihat dari hasil evaluasi yang dilakukan terhadap guru Penjasorkes serta siswa setelah siswa menggunakan media pembelajaran yang dikembangkan meliputi metode pembelajaran serta isi dari media VCD pembelajaran. Hasil uji operasional dilihat dari komponen penilaian siswa terhadap metode pembelajaran dalam uji operasional yang dikembangkan mendapatkan nilai sangat baik yaitu pada 95,63\% dan dari isi VCD pembelajaran telah mencapai pada kriteria sangat baik pada $94,35 \%$. Seluruh rerata penilaian yang diperoleh termasuk ke dalam kriteria sangat baik. Berdasarkan rerata penilaian tersebut, maka media pembelajaran yang dikembangkan dalam penelitian ini dapat digunakan untuk mengajarkan permainan tenis lapangan pada anak sekolah dasar kelas atas. Selain itu dapat membantu para guru Penjasorkes dalam menyampaikan materi pembelajaran permainan bola kecil khususnya tenis lapangan.
\end{abstract}

Kata kunci: media VCD pembelajaran, tenis lapangan, anak SD kelas atas

\begin{abstract}
The purpose of this research is to develop tennis instructional games media used for elementary school children in the upper class. The subjects of this research is students in the upper class of elementary school. This research was Research and Development design. The development was conducted through some steps, i.e.: (1) prestudy, (2) development process, (3) field test. Prestudy covered a reference study and a field study. Development process included goal analysis, ability analysis, learning module design development, and materials and media expert validations. Field test covered restricted a field test, broader field test and operational test. The research instrument used evaluation sheets. The research result shows all aspects in developed learning media, in general, are considered as excellent ones. This appraisal is showed from the result of evaluation which was given by the teacher to his students after the students used that instructional media. The result of operational test showed that students evaluation component toward learning method in operational test get an excellent value of $95.63 \%$ and from the content of instructional media VCD falls in good criteria of 94.35\%. All of the evaluation average reached in an excellent criteria. According to the evaluation, the instructional media can be used to teach tennis ball games among elementary school students in upper class. And it also can help the teacher to deliver the small ball material especially tennis balls.
\end{abstract}

Keywords: instructional media VCD, tennis, elementary school 


\section{Pendahuluan}

Mata pelajaran Penjasorkes sangat berarti bagi siswa karena merupakan media untuk mendorong pertumbuhan fisik, perkembangan psikis, keterampilan motorik, pengetahuan, penalaran, penghayatan nilai-nilai (sikap-mentalemosional-sportivitas-spiritual-sosial) serta pembinaan pola hidup sehat yang pada akhirnya untuk merangsang pertumbuhan dan pertumbuhan kualitas fisik dan psikis yang seimbang dalam diri siswa. Pendidikan Jasmani adalah salah satu mata pelajaran yang diajarkan pada semua tingkat sekolah mulai jenjang Taman Kanak-kanak (TK), Sekolah Dasar (SD), Sekolah Lanjutan Tingkat Pertama (SLTP), Sekolah Lanjutan Tingkat Atas (SLTA), bahkan sampai Perguruan Tinggi. Pendidikan jasmani mempunyai peran besar dalam meningkatkan kebugaran peserta didik, memacu pertumbuhan dan perkembangannya. Manusia yang berkualitas adalah manusia yang memiliki tingkat kebugaran jasmani, intelektual, spiritual dan moralitas yang baik.

Kegiatan pendidikan jasmani di sekolah dasar merupakan kegiatan yang penting untuk pengembangan pendidikan jasmani selanjutnya pada tingkat yang lebih tinggi. Hal ini disebabkan pendidikan jasmani pada tingkat sekolah dasar merupakan peletakan dasar-dasar pokok dari kegiatan tersebut. Dalam pembinaan prestasi olahraga pun harus dimulai sejak usia dini dan dilakukan secara sistematis melalui pendidikan jasmani di sekolah. Hal tersebut telah dijabarkan oleh (Bompa, 1999, pp.35-36) bahwa usia untuk memulai latihan olahraga, khususnya permainan tenis diajarkan pada usia 6-8 tahun.

Pendidikan Jasmani adalah salah satu mata pelajaran yang diajarkan pada semua tingkat sekolah mulai jenjang Taman Kanak-kanak (TK), Sekolah Dasar (SD), Sekolah Lanjutan Tingkat Pertama (SLTP), Sekolah Lanjutan Tingkat Atas (SLTA), bahkan sampai Perguruan Tinggi. Pendidikan jasmani mempunyai peran besar dalam meningkatkan kebugaran peserta didik, memacu pertumbuhan dan perkembangannya. Manusia yang berkualitas adalah manusia yang memiliki tingkat kebugaran jasmani, intelektual, spiritual dan moralitas yang baik.

Ada beberapa faktor yang dapat mempengaruhi cepat lambatnya proses pertumbuhan manusia antara lain: faktor keturunan (genetik), asupan gizi, aktifitas gerak olahraga dan faktor dari luar lainnya misalnya infeksi penyakit, serta kecelakaan. Tiga di antara empat faktor yang mempengaruhi pertumbuhan itu dapat diusahakan perbaikannya yakni: asupan gizi, aktivitas gerak olahraga, dan faktor dari luar. Dengan mengetahui faktor tersebut diharapkan orang tua dan guru dapat mengambil sikap yang tepat agar siswa-siswi dapat tumbuh dan berkembang secara optimal sesuai dengan tingkat usianya.

Situasi dan kondisi di sekolah juga sangat berpengaruh terhadap kelancaran dan kesuksesan dalam pembelajaran Penjasorkes. Sarana dan prasarana yang mendukung dan lengkap pasti akan memudahkan bagi guru dalam mengajar dan siswa dengan mudah menerima pembelajaran dan kurikulum dapat tercapai secara maksimal. Bagaimana dengan sekolah yang kondisi dan situasinya kurang mendukung dalam pembelajaran, seperti sarana prasarana yang kurang lengkap. Peralatan yang dimiliki SD juga sangat minim, tidak semua jenis permainan dan olahraga yang tercantum dalam kurikulum dimiliki SD ini. Hanya beberapa jenis permainan seperti sepakbola, bolavoli, atletik, senam yang terdapat peralatannya itupun kurang dari cukup. Peneliti pun berasumsi bahwa kondisi seperti ini juga dialami oleh sekolah lain. Banyak SD yang tidak mempunyai peralatan yang memadai bahkan ada pula sekolah yang tidak mempunyai lapangan untuk melakukan aktivitas belajar mengajar Penjasorkes. Tidak sedikit guru menyerah dalam keadaan dan hanya mengajarkan apa yang diketahuinya dan apa yang tersedia peralatan olahraganya, mereka enggan dalam berkreasi dan mengembangkan kemampuan dalam menyampaikan materi agar anak mampu berkembang dan tumbuh secara maksimal.

Dalam kurikulum SD terdapat berbagai materi pembelajaran salah satu di antaranya yaitu permainan olahraga bola kecil. Pada umumnya guru hanya akan memberi materi permainan bola kecil seperti rounders dan kasti sedang permainan tenis lapangan tidak pernah diajarkan maupun dikenalkan dikarenakan dalam permainan tenis lapangan yang sebenarnya dapat dilihat ukuran lapangan yang besar dan peralatan yang cukup mahal. Dimungkinkan para guru SD/MI enggan memberikan materi permainan tenis lapangan dikarenakan tidak memiliki lapangan besar dan tidak mampu dalam membeli peralatan tenis. Karena permainan tenis lapangan yang sesungguhnya memerlukan lapangan permanen dan raket yang cukup besar dan berat bagi anak seusia SD/MI, maka para 
guru kesulitan dalam menyampaikan pembelajaran tenis serta siswapun tidak akan pernah mengenal bentuk permainan tenis lapangan.

Pesatnya kemajuan teknologi saat ini masyarakat semakin mengenal VCD, dengan merebaknya VCD bajakan di masyarakat yang dijual bebas di pasar-pasar ataupun pedagang kaki lima. Kebanyakan VCD ini dijual hanya bertemakan musik dan film, untuk pembelajaran khususnya materi Penjasorkes belum ada atau sangat langka. Dengan memiliki VCD dan VCD player siswa dapat memutar berulang kali video yang siswa lihat. Secara tidak langsung masyarakatpun mengenal dan memiliki VCD serta VCD player. Bukan hanya di kalangan masyarakat akhir-akhir ini banyak sekolah yang mulai melengkapi sarana dan prasarana dengan pengadaan multimedia di sekolah.

Usia siswa di sekolah dasar merupakan usia yang potensial untuk pemassalan, pembibitan dan pembinaan cabang olahraga, termasuk salah satunya adalah cabang olahraga tenis lapangan. Dalam proses pembinaan ini secara tidak langsung telah berjalan dengan sendirinya tanpa disadari dengan adanya kegiatan pekan olahraga daerah tingkat sekolah dasar maka para guru akan mencari dan membina siswa yang sesuai dengan kemampuan masing-masing cabang sehingga dapat dirasakan hasilnya saat kompetisi tersebut berlangsung. Untuk itu proses pembelajaran baik materi maupun metode Penjasorkes harus berjalan dengan benar dan tepat dengan mengembangkan 3 aspek pendidikan (afektif, kognitif, psikomotor) sehingga tercapai tujuan pendidikan yang diharapkan. Seiring dengan era informasi dan globalisasi yang merambah negara Indonesia serta reformasi yang tengah berlangsung dengan suasana krisis multidimensi yang menghimpit, teridentifikasi bahwa pendidikan tidak cukup hanya mengedepankan aspek pengetahuan saja.

Penjasorkes yang diajarkan di sekolah memiliki peranan yang sangat penting, peranan tersebut adalah memberikan kesempatan siswa untuk terlibat langsung dalam berbagai pengalaman belajar. Pembekalan pengalaman belajar melalui aktivitas jasmani olahraga dan kesehatan yang terpilih yang dilakukan secara sistematis diarahkan untuk membina pertumbuhan fisik dan pengembangan psikis siswa agar lebih baik, sekaligus membentuk pola hidup sehat dan bugar sepanjang hayat. Pelaksanaan proses pembelajaran Penjasorkes berorientasi pada pencapaian tujuan. Tujuan tersebut dapat dicapai melalui pelaksanaan proses pembelajaran yang baik yang diselenggarakan oleh seorang guru yang memenuhi ketentuan sebagai seorang guru Penjasorkes yakni telah lulus dari pendidikan keguruan melalui bidang pendidikan olahraga dan kesehatan memiliki akta mengajar dan profesi sebagai tenaga pengajar.

Untuk mencapai tujuan tersebut di atas seorang guru harus membuat program pembelajaran. Program pembelajaran harus dibuat sebelum pelaksanaan program kegiatan pembelajaran agar dapat menggambarkan kegiatan yang akan dilaksanakan di lapangan atau di kelas. Pada hakikatnya, suatu pembelajaran yang direncanakan terlebih dahulu akan lebih terarah dan lebih mudah tercapai. Namun sering kali guru beranggapan bahwa mengajar sudah dianggap pekerjaan rutin sehari-hari jadi tidak perlu membuat program pembelajaran atau persiapan sehingga mengajar seadanya tanpa memperhatikan situasi dan kondisi serta kebutuhan siswa.

Situasi dan kondisi di sekolah juga sangat berpengaruh terhadap kelancaran dan kesuksesan dalam pembelajaran Penjasorkes. Sarana dan prasarana yang mendukung dan lengkap pasti akan memudahkan bagi guru dalam mengajar dan siswa dengan mudah menerima pembelajaran dan kurikulum dapat tercapai secara maksimal. Bagaimana dengan sekolah yang kondisi dan situasinya kurang mendukung dalam pembelajaran, seperti sarana prasarana yang kurang lengkap?

Berbagai permasalahan mucul dalam dunia pendidikan dasar, dan permasalahan itu sangat mengganggu dalam peningkatan potensi siswa. Pembelajaran yang berlangsung masih banyak dilakukan dengan metode klasik, dimana pembelajaran berpusat pada guru dan siswa hanya sebagai objek yang harus selalu memperhatikan guru sebagai pusat informasi. Guru kurang memberikan materi yang beragam dalam mata pelajaran Penjasorkes. Pengetahuan siswa dan kemampuan guru Penjasorkes dalam menyampaikan materi tentang permainan tenis lapangan masih rendah. Media pembelajaran VCD yang mampu mengakomodir materi Penjasorkes tenis lapangan di sekolah.

Melihat fenomena di atas maka peneliti ingin mengembangkan sebuah media VCD pembelajaran tenis lapangan pada siswa sekolah dasar kelas atas sehingga mampu meningkatkan pengetahuan dan kualitas keterampilan permainan tenis lapangan bagi siswa SD kelas atas. Namun pembelajaran tenis lapangan yang diajarkan dalam lingkup SD dimodifikasi terlebih 
dahulu. Perlu diciptakan dan dikembangkan suatu model pembelajaran permainan tenis yang sederhana dengan cara memodifikasi permainan tenis, agar mudah, murah, manfaat, dan masal, sehingga dapat diajarkan di setiap SD/MI di Indonesia (Sukadiyanto, 2003, p.25). Modifikasi dalam hal ini yaitu peralatan yang digunakan bukanlah peralatan yang sebenarnya artinya peralatan yang telah dimodifikasi tanpa mengurangi fungsi dasarnya hanya disesuaikan dengan keadaan lingkungan SD/MI dan karakteristik siswa, sehingga tenis lapangan dapat diajarkan di sekolah dasar dengan peralatan dan fasilitas yang dimodifikasi.

Diharapkan media pembelajaran VCD ini mampu mengatasi kekurangan media pembelajaran yang dialami di sekolah dan mampu meningkatkan semangat, kreativitas serta kemampuan seorang guru dengan mengembangkan media pembelajaran. Guru tidak lagi hanya bergantung pada materi, peralatan dan media yang tersedia namun mereka mampu menciptakan media dan perangkat pembelajaran yang sesuai dengan kondisi di setiap sekolah. Siswa juga dapat meningkatkan pengetahuan serta keterampilan permainan tenis lapangan tanpa tergantung oleh guru maupun pelatih. Asumsinya semakin banyak siswa yang melihat dan tertarik dengan permainan ini semakin banyak pula siswa yang mau belajar permainan tenis lapangan sehingga pemassalan olahraga cabang tenis lapangan akan tercapai harapannya akan tercipta atlet-atlet daerah maupun nasional yang mampu berkiprah di lingkup internasional.

\section{Metode}

Jenis Penelitian

Penelitian yang dilakukan ini menggunakan model penelitian dan pengembangan, tujuannya untuk mengembangkan produk pembelajaran berupa multimedia pembelajaran berbentuk VCD (Video Compact Disc) bagi anakanak sekolah dasar kelas atas, yang isinya memuat materi pembelajaran permainan tenis lapangan yang dapat dimanfaatkan dalam proses pembelajaran pada mata pelajaran Penjasorkes.

\section{Waktu dan Tempat Penelitian}

Waktu yang dilakukan dalam penelitian dan pengembangan media pembelajaran VCD tenis lapangan ini yaitu bulan Desember 2011 sampai dengan bulan April 2012. Sedangkan tempat penelitian yaitu SDN Gejagan dan SDN
Petung 1 Kecamatan Pakis, Kabupaten Magelang.

\section{Subjek Penelitian}

Subjek penelitian ini diambil dalam penelitian ini adalah satu orang pakar pembelajaran permainan yang berkompeten di dalam pembelajaran permainan dan satu orang pakar media dalam uji pakar atau expert judgment. Dalam uji coba terbatas 1 kelas atas yaitu kelas 5 yang berjumlah 31 siswa, dengan 1 orang guru Penjasorkes dari SDN Gejagan Kecamatan Pakis. Uji coba luas: 3 kelas yaitu kelas 4 berjumlah 21 siswa, kelas 5 berjumlah 31, dan kelas 6 berjumlah 19 siswa serta 1 orang guru Penjasorkes juga diambil dari siswa SDN Gejagan Kecamatan Pakis. sedangkan dalam uji operasional sebanyak 71 siswa diambil dari SDN Petung I Kecamatan Pakis.

\section{Prosedur}

Prosedur pengembangan yang dilakukan dalam penelitian pengembangan ini meliputi prosedur pengembangan produk, prosedur pengembangan desain pembelajaran, dan prosedur pengembangan multimedia pembelajaran. Secara umum, penelitian pengembangan ini dilakukan dengan mengikuti langkah-langkah yang telah dibuat dalam model pengembangan (Borg and Gall, 1989) yang dikelompokkan ke dalam empat tahapan pengembangan, dimana tahapan dalam pengembangan yang dilakukan tersebut meliputi: (a) studi pendahuluan, (b) pengembangan, (c) uji lapangan, dan (d) diseminasi (pengenalan produk).

Data, Instrumen, dan Teknik Pengumpulan Data

Jenis data awal yang diperoleh pada penelitian pengembangan ini adalah data kualitatif dan data kuantitatif. Pengumpulan data kualitatif didapatkan dari hasil observasi, masukan dari pakar pembelajaran dan dari hasil wawancara dengan guru. Data kuantitatif diperoleh dari ahli materi, terhadap draft produk, serta dari guru Penjasorkes dan siswa dalam uji coba lapangan.

Instrumen dalam penelitian ini yaitu menggunakan uji validitas dari pakar dengan lembar validasi. Uji coba terbatas dan uji coba luas menggunakan instrumen lembar observasi, pedoman wawancara dan angket dari guru Penjasorkes dan siswa. 


\section{Teknik Analisis Data}

Analisis data yang validasi dari pakar adalah dengan menggunakan teknik analisis deskriptif kualitatif. Frekuensi tiap-tiap skor dihitung untuk mengetahui persentase dari kategori sangat baik (5), baik (4), cukup (3), kurang (2), dan sangat kurang (1) Analisis ini dimaksudkan untuk menggambarkan karakteristik data pada masing-masing variabel. Dengan ini diharapkan akan mempermudah memahami data untuk proses analisis selanjutnya. Hasil analisis data digunakan sebagai dasar untuk merevisi produk modul yang dikembangkan.

Data kuantitatif yang diperoleh melalui angket penilaian dan dianalisis dengan menggunakan statistik deskriptif kemudian dikonversikan ke data kualitatif yang diadaptasi dari (Sukardjo, 2005, p.55). Lebih jelasnya dapat di lihat pada tabel.

Tabel 1. Konversi Data Kuantitatif ke Data Kualitatif dengan Skala 5

\begin{tabular}{ccc}
\hline $\begin{array}{c}\text { Data } \\
\text { Kuantitatif }\end{array}$ & Rentang & $\begin{array}{c}\text { Data } \\
\text { Kualitatif }\end{array}$ \\
\hline 5 & $\mathrm{X}>\mathrm{Xi}+1,80 \mathrm{Sbi}$ & $\begin{array}{c}\text { Sangat } \\
\text { Baik }\end{array}$ \\
4 & $\mathrm{Xi}+0,60 \mathrm{Sbi}<\mathrm{X} \leq \mathrm{Xi}+$ & Baik \\
& $\mathrm{1}, 80 \mathrm{Sbi}$ & \\
3 & $\mathrm{Xi}-0,60 \mathrm{Sbi}<\mathrm{X} \leq \mathrm{Xi}+$ & Cukup \\
& $0,60 \mathrm{Sbi}$ & \\
2 & $\mathrm{Xi}-1,80 \mathrm{Sbi}<\mathrm{X} \leq \mathrm{Xi}-$ & Kurang \\
& $0,60 \mathrm{Sbi}$ & Sangat \\
1 & $\mathrm{X} \leq \mathrm{Xi}-1,80 \mathrm{Sbi}$ & Kurang \\
\hline
\end{tabular}

Keterangan:

$\mathrm{Xi}=$ Rerata ideal

$=1 / 2($ skor $m a k+$ skor min $)$

Sbi $=$ Simpang baku ideal

$=1 / 6($ skor mak - skor min $)$

$\mathrm{X}=$ Skor aktual

Untuk mendapatkan data rerata hasil penilaian yang akan digunakan sebagai kesimpulan, digunakan rumus:

Rerata Penilaian $=\frac{\text { Total Penilaian }}{\sum \text { Aspek diamati } \times \sum \text { Siswa }}$

\section{Hasil Penelitian dan Pengembangan}

Validasi Ahli Pembelajaran

Pengembangan produk awal dilakukan dengan merumuskan tujuan pembelajaran yang ingin dicapai, kemudian melakukan validasi ah- li. Data validasi ahli digunakan untuk merevisi produk sebelum dilakukan uji coba lapangan.

Tabel 2. Evaluasi Ahli Materi Pembelajaran

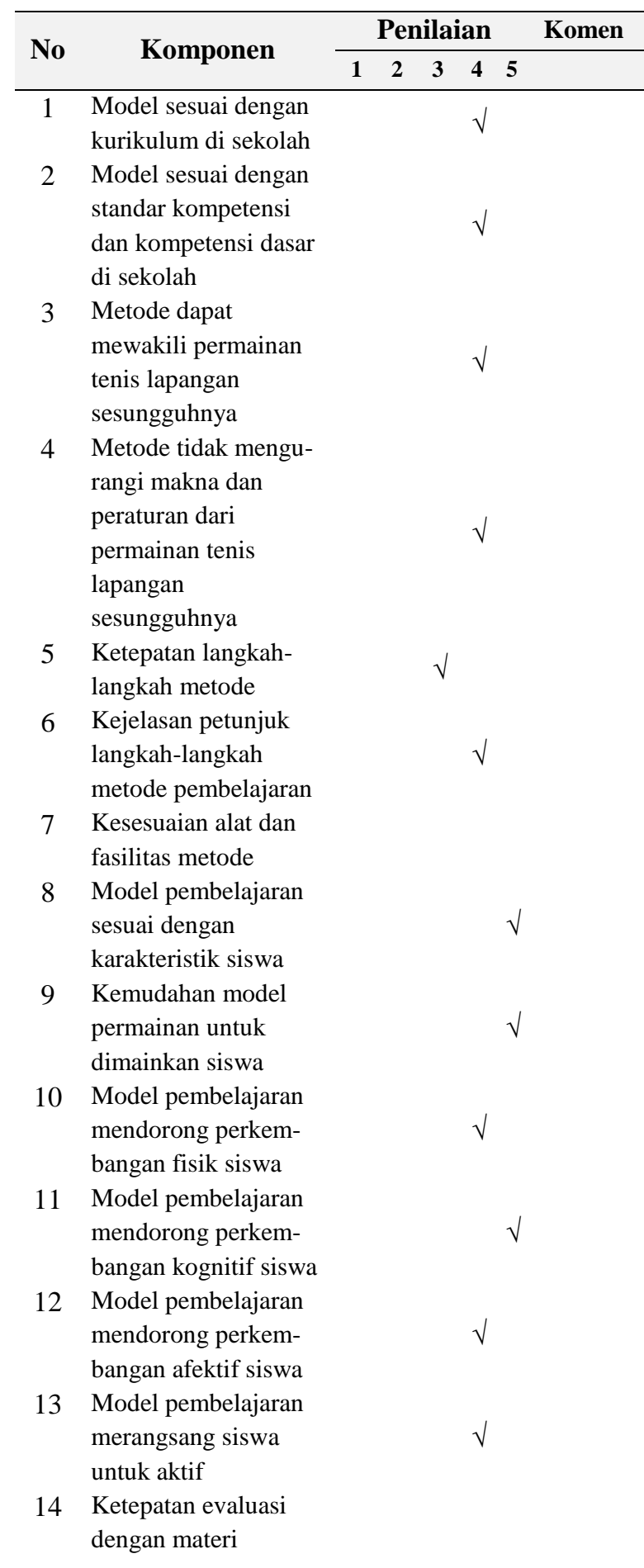

Berdasarkan rumus konversi data di atas, maka setelah didapatkan data-data kuantitatif, untuk mengubahnya ke dalam data kualitatif pada pengembangan ini diterapkan konversi sebagai berikut: 


$\begin{array}{ll}\text { Skor Mak } & =5 \\ \text { Skor Min } & =1 \\ \text { Xi } & =1 / 2(5+1) \\ & =3 \\ \text { Sbi } & =1 / 6(5-1) \\ \text { Skala 5 } & =0,6 \\ & =\mathrm{X}>3+(1,8 \times 0,6) \\ \text { Skala } 4 & =\mathrm{X}>3+1,08 \\ & =3+(0,6 \times 0,6)<\mathrm{X} \leq 4,08 \\ \text { Skala 3 } & =3+0,36<\mathrm{X} \leq 4,08 \\ & =3,36<\mathrm{X} \leq 4,08 \\ \text { Skala 2 } & =2,64<\mathrm{X} \leq 3,36 \\ & =3-(1,8 \times 0,6)<\mathrm{X} \leq 2,64 \\ \text { Skala 1 } & =3-1,08<\mathrm{X} \leq 2,64 \\ & =1,92<\mathrm{X} \leq 2,64 \\ & =\mathrm{X} \leq 1,92\end{array}$

Atas dasar perhitungan di atas maka konversi data kuantitatif ke data kualitatif skala 5 maka, jumlah penilaian dari validasi yang dilakukan oleh ahli materi adalah 62 dan bila dilakukan rerata maka dihasilkan nilai 4,13. Bila dikonversikan berdasarkan tabel konversi di atas, maka hasil penilaian dari ahli materi berada pada rentang $X>4,08$ yang secara keseluruhan hasilnya adalah sangat baik.

\section{Validasi Ahli Media}

Validasi ahli media dalam pembelajaran ini yaitu Herman Dwi Surjono, Ph.D. beliau saat ini menjabat sebagai Ketua Program Studi Teknologi Pembelajaran, PPs UNY sekaligus sebagai pengajar. Sebelum mengisi angket yang telah disediakan oleh peneliti, ahli media terlebih dahulu mempelajari media pembelajaran VCD permainan tenis lapangan untuk siswa SD kelas atas. Dalam proses validasi, ahli materi berdiskusi dan menanyakan secara langsung kepada peneliti tentang media pembelajaran yang akan dikembangkan.

Berikut ini adalah hasil data validasi serta kritik dan saran oleh ahli media dalam tahap draft media pembelajaran VCD permainan tenis lapangan.
Tabel 3. Validasi Ahli Media

\begin{tabular}{|c|c|c|c|c|c|}
\hline \multirow{2}{*}{ No } & \multirow{2}{*}{ Komponen } & \multicolumn{3}{|c|}{ Penilaian } & \multirow[t]{2}{*}{ Komen } \\
\hline & & 12 & 3 & 45 & \\
\hline 1 & $\begin{array}{l}\text { Kualitas tampilan } \\
\text { gambar }\end{array}$ & & & $\sqrt{ }$ & \\
\hline 2 & $\begin{array}{l}\text { Kualitas tampilan } \\
\text { layar }\end{array}$ & & $\sqrt{ }$ & & $\begin{array}{l}\text { Resolusi } \\
\text { kurang } \\
\text { fungsi }\end{array}$ \\
\hline 3 & $\begin{array}{l}\text { Ketepatan } \\
\text { penggunaan narasi }\end{array}$ & & & $\sqrt{ }$ & \\
\hline 4 & $\begin{array}{l}\text { Ketepatan volume } \\
\text { narasi }\end{array}$ & & & $\sqrt{ }$ & \\
\hline 5 & $\begin{array}{l}\text { Ketepatan ukuran } \\
\text { huruf }\end{array}$ & & & $\sqrt{ }$ & \\
\hline 6 & $\begin{array}{l}\text { Ketepatan warna } \\
\text { huruf }\end{array}$ & & & $\sqrt{ }$ & \\
\hline 7 & Komposisi warna & & & $\sqrt{ }$ & \\
\hline 8 & $\begin{array}{l}\text { Tingkat interaktiv- } \\
\text { itas siswa dengan } \\
\text { media }\end{array}$ & & $\sqrt{ }$ & & \\
\hline 9 & $\begin{array}{l}\text { Daya dukung } \\
\text { musik }\end{array}$ & & & $\sqrt{ }$ & \\
\hline 10 & $\begin{array}{l}\text { Keterbacaan pesan } \\
\text { pembelajaran }\end{array}$ & & & $\sqrt{ }$ & \\
\hline
\end{tabular}

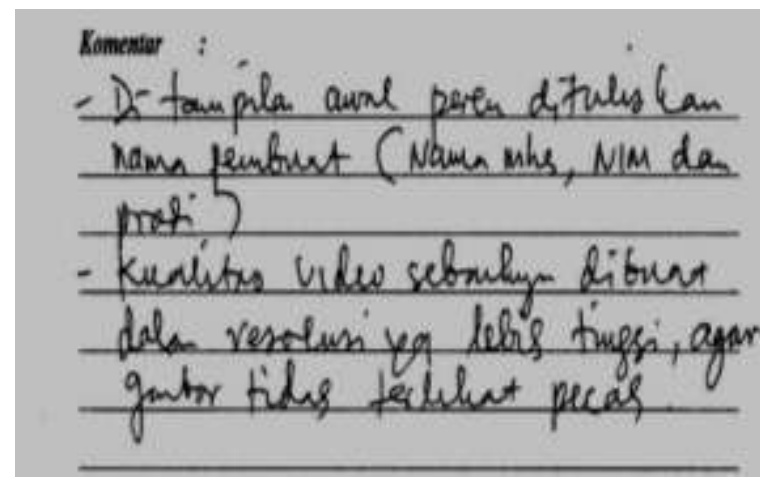

Jumlah penilaian dari validasi yang dilakukan oleh ahli media adalah 38 dan bila dilakukan rerata maka dihasilkan nilai 3,8. Bila dikonversikan berdasarkan tabel konversi di atas, maka hasil penilaian dari ahli media berada pada rentang $3,36<X \leq 4,08$ yang secara keseluruhan hasilnya adalah baik.

Setelah mendapatkan hasil validasi oleh ahli materi pembelajaran dan ahli media, maka dilakukan revisi produk. Hasil dari revisi produk inilah yang kemudian media pembelajaran VCD tenis lapangan bagi siswa SD kelas atas ini di uji coba.

\section{Deskripsi Data Uji Coba Terbatas}

Uji lapangan terbatas dilakukan setelah didapatkan validasi dari ahli materi pembelajaran dan ahli media. Setelah dinyatakan layak untuk dilakukan uji coba lapangan dan tidak ada revisi maka VCD pembelajaran tenis lapangan 
bagi siswa SD ini diujicobakan pada lapangan terbatas. Uji coba lapangan terbatas melibatkan siswa kelas 5 di SD Gejagan Kecamatan Pakis Kabupaten Magelang, yaitu 31 orang siswa sekolah dasar kelas atas.

Dari uji coba terbatas didapatkan data hasil berupa evaluasi dengan menggunakan angket untuk guru Penjasorkes dan siswa yang dikenai perlakuan atau sebagai objek penelitian. Untuk guru Penjasorkes didapatkan hasil evaluasi sebagai berikut:

Tabel 4. Angket Guru dari Uji Coba Terbatas

\begin{tabular}{|c|c|c|c|c|c|}
\hline \multirow{2}{*}{ No } & \multirow{2}{*}{ Komponen } & \multicolumn{3}{|c|}{ Penilaian } & \multirow[t]{2}{*}{ Komen } \\
\hline & & 12 & 3 & 45 & \\
\hline 1 & $\begin{array}{l}\text { Model sesuai dengan } \\
\text { kurikulum di sekolah }\end{array}$ & & & $\sqrt{ }$ & \\
\hline 2 & $\begin{array}{l}\text { Model sesuai dengan } \\
\text { standar kompetensi } \\
\text { dan kompetensi dasar } \\
\text { di sekolah }\end{array}$ & & & $\sqrt{ }$ & \\
\hline 3 & $\begin{array}{l}\text { Metode dapat } \\
\text { mewakili permainan } \\
\text { tenis lapangan } \\
\text { sesungguhnya }\end{array}$ & & & $\sqrt{ }$ & \\
\hline 4 & $\begin{array}{l}\text { Metode tidak mengu- } \\
\text { rangi makna dan } \\
\text { peraturan dari } \\
\text { permainan tenis } \\
\text { lapangan } \\
\text { sesungguhnya }\end{array}$ & & & $\sqrt{ }$ & \\
\hline 5 & $\begin{array}{l}\text { Ketepatan langkah- } \\
\text { langkah metode }\end{array}$ & & & $\sqrt{ }$ & \\
\hline 6 & $\begin{array}{l}\text { Kejelasan petunjuk } \\
\text { langkah-langkah } \\
\text { metode pembelajaran }\end{array}$ & & & $\sqrt{ }$ & \\
\hline 7 & $\begin{array}{l}\text { Kesesuaian alat dan } \\
\text { fasilitas metode }\end{array}$ & & & $\sqrt{ }$ & \\
\hline 8 & $\begin{array}{l}\text { Model pembelajaran } \\
\text { sesuai dengan } \\
\text { karakteristik siswa }\end{array}$ & & & $\sqrt{ }$ & \\
\hline 9 & $\begin{array}{l}\text { Kemudahan model } \\
\text { permainan untuk } \\
\text { dimainkan siswa }\end{array}$ & & & $\sqrt{ }$ & \\
\hline 10 & $\begin{array}{l}\text { Model pembelajaran } \\
\text { mendorong perkem- } \\
\text { bangan fisik siswa }\end{array}$ & & & $\sqrt{ }$ & \\
\hline 11 & $\begin{array}{l}\text { Model pembelajaran } \\
\text { mendorong perkem- } \\
\text { bangan kognitif siswa }\end{array}$ & & & $\sqrt{ }$ & \\
\hline 12 & $\begin{array}{l}\text { Model pembelajaran } \\
\text { mendorong perkem- } \\
\text { bangan afektif siswa }\end{array}$ & & & $\sqrt{ }$ & \\
\hline 13 & $\begin{array}{l}\text { Model pembelajaran } \\
\text { merangsang siswa } \\
\text { untuk aktif }\end{array}$ & & & $\sqrt{ }$ & \\
\hline 14 & $\begin{array}{l}\text { Ketepatan evaluasi } \\
\text { dengan materi }\end{array}$ & & & $\sqrt{ }$ & \\
\hline
\end{tabular}

Jumlah penilaian dari validasi yang dilakukan oleh ahli materi adalah 62 dan bila dilakukan rerata maka dihasilkan nilai 4,13. Bila dikonversikan berdasarkan tabel konversi, maka hasil penilaian dari guru Penjasorkes berada pada rentang $X>4,08$ yang secara keseluruhan hasilnya adalah sangat baik.

Selain mendapat hasil angket pernyataan dari guru pengajar Penjasorkes penelitian ini juga mendapat hasil angket dari siswa sebagai objek penelitian pengembangan permainan tenis lapangan bagi anak sekolah dasar kelas atas. Adapun hasil angket dari siswa yaitu sebagai berikut:

Tabel 5. Angket Siswa Uji Lapangan Terbatas

\begin{tabular}{|c|c|c|c|}
\hline \multirow{2}{*}{ No. } & \multirow{2}{*}{ Pernyataan } & \multicolumn{2}{|c|}{ Persen (\%) } \\
\hline & & Ya & Tidak \\
\hline 1 & $\begin{array}{l}\text { Apakah anda bisa melakukan } \\
\text { permainan yang diajarkan? }\end{array}$ & 100 & 0 \\
\hline 2 & $\begin{array}{l}\text { Apakah anda memahami per- } \\
\text { aturan yang diajarkan? }\end{array}$ & 87.09 & 12,91 \\
\hline 3 & $\begin{array}{l}\text { Apakah anda kesulitan untuk } \\
\text { melakukan permainan yang } \\
\text { diajarkan? }\end{array}$ & 9,68 & 90,32 \\
\hline 4 & $\begin{array}{l}\text { Apakah permainan tersebut } \\
\text { menyenangkan? }\end{array}$ & 100 & 0 \\
\hline 5 & $\begin{array}{l}\text { Apakah permainan tersebut } \\
\text { membuat anda bersemangat? }\end{array}$ & 100 & 0 \\
\hline 6 & $\begin{array}{l}\text { Apakah dengan media pem- } \\
\text { belajaran ini anda lebih mu- } \\
\text { dah memahami gerakan dan } \\
\text { teknik bermain? }\end{array}$ & 100 & 0 \\
\hline 7 & $\begin{array}{l}\text { Apakah dengan melihat video } \\
\text { pembelajaran ini membantu } \\
\text { anda dalam melakukan latihan } \\
\text { tenis lapangan lebih mudah? }\end{array}$ & 100 & 0 \\
\hline 8 & $\begin{array}{l}\text { Apakah anda bisa mengopera- } \\
\text { sikan media pembelajaran itu } \\
\text { sendiri? }\end{array}$ & 67,74 & 32,26 \\
\hline 9 & $\begin{array}{l}\text { Apakah anda bisa memahami } \\
\text { mempelajari dan melaksana- } \\
\text { kan yang ditampilkan dalam } \\
\text { video? }\end{array}$ & 64,52 & 35,48 \\
\hline 10 & $\begin{array}{l}\text { Apakah anda akan melakukan } \\
\text { permainan ini dalam waktu } \\
\text { senggang tanpa diminta/disu- } \\
\text { ruh guru? }\end{array}$ & 80,66 & 19,34 \\
\hline
\end{tabular}

Berdasarkan tabel di atas dapat diketahui bahwa hasil penilaian yang diberikan oleh 31 siswa. Dari seluruh responden siswa yang berjumlah 31 menjawab ya/setuju 100\% untuk 5 (lima) pertanyaan yang berhubungan dengan permainan yang diajarkan. Untuk komponen pertanyaan memahami peraturan yang diajarkan masih ada sekitar $12,91 \%$ atau 4 siswa yang merespon belum memahami peraturan. Sebanyak 3 siswa atau 9,68\% masih merasa kesulitan. Untuk pengoperasian media pembelajaran berupa VCD baru 21 siswa atau $67,74 \%$ yang sudah bisa. Untuk pertanyaan mempelajari dan melaksanakan yang ditampilkan dalam video baru 20 siswa atau $64,52 \%$. Sedangkan untuk 
pertanyaan apakah anda akan melakukan permainan ini dalam waktu senggang tanpa diminta guru? mencapai 25 siswa atau sebanyak $80,66 \%$ dari seluruh siswa.

\section{Deskripsi Data Uji Coba Luas}

Berdasarkan hasil uji lapangan terbatas, media yang dikembangkan oleh peneliti layak untuk diujikan ke dalam uji lapangan yang lebih luas. Seperti juga pada uji coba lapangan terbatas, pada uji coba lapangan lebih luas diperoleh data hasil dari unsur guru Penjasorkes serta penilaian siswa. Data hasil uji coba lebih luas yang didapatkan berupa evaluasi dengan menggunakan angket untuk guru Penjasorkes didapatkan hasil sebagai berikut:

Tabel 6. Hasil Angket Guru Uji Coba Luas

\begin{tabular}{|c|c|c|c|c|c|}
\hline \multirow{2}{*}{ No } & \multirow{2}{*}{ Komponen } & \multicolumn{3}{|c|}{ Penilaian } & \multirow[t]{2}{*}{ Komen } \\
\hline & & 12 & 3 & 45 & \\
\hline 1 & $\begin{array}{l}\text { Model sesuai dengan } \\
\text { kurikulum di sekolah }\end{array}$ & & & $\sqrt{ }$ & \\
\hline 2 & $\begin{array}{l}\text { Model sesuai dengan } \\
\text { standar kompetensi } \\
\text { dan kompetensi dasar } \\
\text { di sekolah }\end{array}$ & & & $\sqrt{ }$ & \\
\hline 3 & $\begin{array}{l}\text { Metode dapat } \\
\text { mewakili permainan } \\
\text { tenis lapangan } \\
\text { sesungguhnya }\end{array}$ & & & $\sqrt{ }$ & \\
\hline 4 & $\begin{array}{l}\text { Metode tidak mengu- } \\
\text { rangi makna dan } \\
\text { peraturan dari } \\
\text { permainan tenis } \\
\text { lapangan } \\
\text { sesungguhnya }\end{array}$ & & & $\sqrt{ }$ & \\
\hline 5 & $\begin{array}{l}\text { Ketepatan langkah- } \\
\text { langkah metode }\end{array}$ & & & $\sqrt{ }$ & \\
\hline 6 & $\begin{array}{l}\text { Kejelasan petunjuk } \\
\text { langkah-langkah } \\
\text { metode pembelajaran }\end{array}$ & & & $\sqrt{ }$ & \\
\hline 7 & $\begin{array}{l}\text { Kesesuaian alat dan } \\
\text { fasilitas metode }\end{array}$ & & & $\sqrt{ }$ & \\
\hline 8 & $\begin{array}{l}\text { Model pembelajaran } \\
\text { sesuai dengan } \\
\text { karakteristik siswa }\end{array}$ & & & $\sqrt{ }$ & \\
\hline 9 & $\begin{array}{l}\text { Kemudahan model } \\
\text { permainan untuk } \\
\text { dimainkan siswa }\end{array}$ & & & $\sqrt{ }$ & \\
\hline 10 & $\begin{array}{l}\text { Model pembelajaran } \\
\text { mendorong perkem- } \\
\text { bangan fisik siswa }\end{array}$ & & & $\sqrt{ }$ & \\
\hline 11 & $\begin{array}{l}\text { Model pembelajaran } \\
\text { mendorong perkem- } \\
\text { bangan kognitif siswa }\end{array}$ & & & $\sqrt{ }$ & \\
\hline 12 & $\begin{array}{l}\text { Model pembelajaran } \\
\text { mendorong perkem- } \\
\text { bangan afektif siswa }\end{array}$ & & & $\sqrt{ }$ & \\
\hline 13 & $\begin{array}{l}\text { Model pembelajaran } \\
\text { merangsang siswa } \\
\text { untuk aktif }\end{array}$ & & & $\sqrt{ }$ & \\
\hline 14 & $\begin{array}{l}\text { Ketepatan evaluasi } \\
\text { dengan materi }\end{array}$ & & & $\sqrt{ }$ & \\
\hline
\end{tabular}

Jumlah penilaian dari validasi yang dilakukan oleh ahli materi adalah 65 dan bila dilakukan rerata maka dihasilkan nilai 4,33. Bila dikonversikan berdasarkan tabel konversi, maka hasil penilaian dari guru Penjasorkes berada pada rentang $X>4,08$ yang secara keseluruhan hasilnya adalah sangat baik.

Uji lapangan yang lebih luas ini melibatkan 71 orang siswa sekolah dasar kelas atas di SD Negeri Gejagan yang terletak di Desa Gejagan, Kecamatan Pakis, Kabupaten Magelang, dengan rincian 21 siswa kelas 4, 31siswa kelas 5 dan 19 siswa kelas 6 . Uji lapangan yang lebih luas ini dilaksanakan pada bulan Maret 2012.

Selain mendapat hasil angket pernyataan dari guru Penjasorkes penelitian ini juga mendapat hasil angket dari siswa yang lebih banyak dari uji lapangan terbatas sebagai objek penelitian. Adapun hasil angket dari siswa yaitu sebagai berikut:

Tabel 7. Hasil Evaluasi Siswa Pada Uji Lapangan Lebih Luas

\begin{tabular}{|c|c|c|c|}
\hline \multirow{2}{*}{ No } & \multirow{2}{*}{ Pernyataan } & \multicolumn{2}{|c|}{ Persentase (\%) } \\
\hline & & $\mathbf{Y a}$ & Tidak \\
\hline 1 & $\begin{array}{l}\text { Apakah anda bisa melakukan } \\
\text { permainan yang diajarkan? }\end{array}$ & 100 & 0 \\
\hline 2 & $\begin{array}{l}\text { Apakah anda memahami per- } \\
\text { aturan yang diajarkan? }\end{array}$ & 90,14 & 13 \\
\hline 3 & $\begin{array}{l}\text { Apakah anda kesulitan untuk } \\
\text { melakukan permainan yang } \\
\text { diajarkan? }\end{array}$ & 5,63 & 94,37 \\
\hline 4 & $\begin{array}{l}\text { Apakah permainan tersebut } \\
\text { menyenangkan? }\end{array}$ & 100 & 0 \\
\hline 5 & $\begin{array}{l}\text { Apakah permainan tersebut } \\
\text { membuat anda bersemangat? }\end{array}$ & 100 & 0 \\
\hline 6 & $\begin{array}{l}\text { Apakah dengan media pem- } \\
\text { belajaran ini anda lebih mu- } \\
\text { dah memahami gerakan dan } \\
\text { teknik bermain? }\end{array}$ & 100 & 0 \\
\hline 7 & $\begin{array}{l}\text { Apakah dengan melihat video } \\
\text { pembelajaran ini membantu } \\
\text { anda dalam melakukan latih- } \\
\text { an tenis lapangan lebih } \\
\text { mudah? }\end{array}$ & 100 & 0 \\
\hline 8 & $\begin{array}{l}\text { Apakah anda bisa mengope- } \\
\text { rasikan media pembelajaran } \\
\text { itu sendiri? }\end{array}$ & 83,09 & 16,91 \\
\hline 9 & $\begin{array}{l}\text { Apakah anda bisa memahami } \\
\text { mempelajari dan melaksana- } \\
\text { kan yang ditampilkan dalam } \\
\text { video? }\end{array}$ & 85,91 & 14,09 \\
\hline 10 & $\begin{array}{l}\text { Apakah anda akan melaku- } \\
\text { kan permainan ini dalam wak- } \\
\text { tu senggang tanpa diminta } \\
\text { guru? }\end{array}$ & 84,51 & 15,49 \\
\hline
\end{tabular}


Berdasarkan tabel di atas dapat diketahui bahwa terjadi peningkatan penilaian yang diberikan siswa pada uji coba lapangan lebih luas. Walaupun nilai peningkatan tidak terlalu signifikan, namun terlihat adanya perbaikan penilaian hampir di semua pertanyaan, dapat di lihat dari diagram Gambar 1 berikut ini:

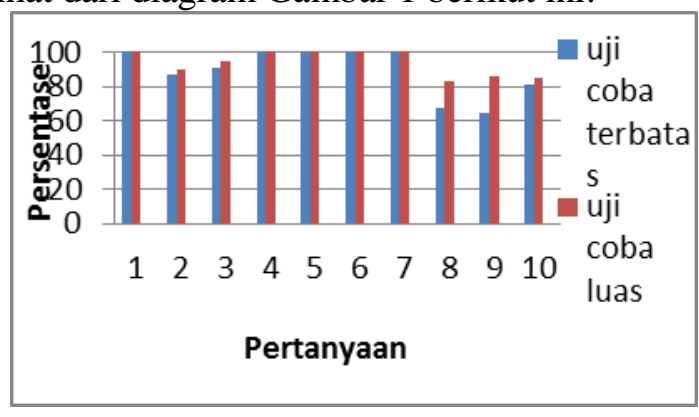

Gambar 1. Diagram Peningkatan Uji Coba Terbatas ke Uji Coba Luas

Berdasarkan diagram batang di atas menunjukkan bahwa setiap aspek pertanyaan mengalami peningkatan. Untuk pertanyaan nomor $1,4,5,6,7$ pada posisi $100 \%$, sedangkan pertanyaan nomor $2,3,8,9,10$ penilaian siswa mengalami peningkatkan yang signifikan.

Tabel 8. Angket Siswa Uji Operasional

\begin{tabular}{|c|c|c|c|}
\hline \multirow{2}{*}{ No } & \multirow{2}{*}{ Pernyataan } & \multicolumn{2}{|c|}{ Persen (\%) } \\
\hline & & Ya & Tidak \\
\hline 1 & $\begin{array}{l}\text { Apakah anda bisa melakukan } \\
\text { permainan yang diajarkan? }\end{array}$ & 100 & 0 \\
\hline 2 & $\begin{array}{l}\text { Apakah anda memahami per- } \\
\text { aturan yang diajarkan? }\end{array}$ & 91,40 & 8,60 \\
\hline 3 & $\begin{array}{l}\text { Apakah anda kesulitan untuk } \\
\text { melakukan permainan yang } \\
\text { diajarkan? }\end{array}$ & 4,30 & 95,70 \\
\hline 4 & $\begin{array}{l}\text { Apakah permainan tersebut } \\
\text { menyenangkan? }\end{array}$ & 100 & 0 \\
\hline 5 & $\begin{array}{l}\text { Apakah permainan tersebut } \\
\text { membuat anda bersemangat? }\end{array}$ & 100 & 0 \\
\hline 6 & $\begin{array}{l}\text { Apakah dengan media pem- } \\
\text { belajaran ini anda lebih mudah } \\
\text { memahami gerakan dan teknik } \\
\text { bermain? }\end{array}$ & 100 & 0 \\
\hline 7 & $\begin{array}{l}\text { Apakah dengan melihat video } \\
\text { pembelajaran ini membantu } \\
\text { anda dalam melakukan latihan } \\
\text { tenis lapangan lebih mudah? }\end{array}$ & 100 & 0 \\
\hline 8 & $\begin{array}{l}\text { Apakah anda bisa mengopera- } \\
\text { sikan media pembelajaran itu } \\
\text { sendiri? }\end{array}$ & 86,02 & 13,98 \\
\hline 9 & $\begin{array}{l}\text { Apakah anda bisa memahami } \\
\text { mempelajari dan melaksanakan } \\
\text { yang ditampilkan dalam video? }\end{array}$ & 91,40 & 8,60 \\
\hline 10 & $\begin{array}{l}\text { Apakah anda akan melakukan } \\
\text { permainan ini dalam waktu } \\
\text { senggang tanpa diminta/disuruh } \\
\text { guru? }\end{array}$ & 89,25 & 10,75 \\
\hline
\end{tabular}

Dapat dilihat dari Tabel 8 bahwa terjadi peningkatan penilaian yang diberikan siswa pada uji coba operasional. Peningkatan tidak terlalu signifikan, namun terlihat adanya perbaikan penilaian hampir di semua pertanyaan, dapat di lihat dari diagram Gambar 2 berikut ini:

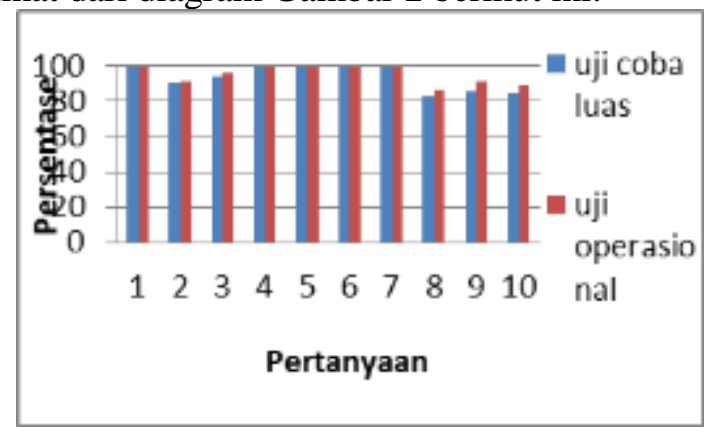

Gambar 2. Diagram Batang Peningkatan Uji Coba Luas ke Uji Operasional

Berdasarkan Gambar 2 diagram batang di atas menunjukkan bahwa setiap aspek pertanyaan mengalami peningkatan. Untuk pertanyaan nomor 1, 4, 5, 6 dan 7 masih mendapatkan penilaian tertinggi dari siswa dan tetap berada pada posisi $100 \%$, sedangkan untuk pertanyaan nomor 2, 3, 8, 9 dan 10 penilaian dari uji lapangan lebih luas ke uji operasional mengalami peningkatan yang cukup signifikan.

Uji operasional dilakukan di sekolah lain dengan asumsi apakah media pembelajaran yang dikembangkan oleh peneliti ini baik untuk digunakan dalam proses pembelajaran bagi siswa SD kelas atas tidak hanya dalam satu sekolah saja. Uji operasional ini juga digunakan untuk melihat apakah model pembelajaran yang dikembangkan dapat digunakan untuk meningkatkan keterampilan tenis lapangan pada siswa sekolah dasar kelas atas. Uji operasional bila dilihat dari nilai rerata secara keseluruhan menunjukkan kesimpulan penilaian yang sangat baik.

Komponen penilaian siswa terhadap metode pembelajaran dalam uji operasional yang dikembangkan mendapatkan nilai sangat baik. Dengan hasil tersebut maka siswa sudah dapat mengikuti metode pembelajaran yang disampaikan Dalam hal isi dari media siswa memberikan penilaian terhadap isi dari VCD pembelajaran telah mencapai pada kriteria sangat baik.

\section{Simpulan dan Saran}

Simpulan

Telah dihasilkan pengembangan media pembelajaran VCD tenis lapangan bagi siswa 
SD kelas atas yang isi materi sesuai dengan karakteristik siswa SD kelas atas. Media pembelajaran VCD permainan tenis lapangan yang dikembangkan dalam penelitian ini layak digunakan sebagai salah satu media pembelajaran untuk meningkatkan keterampilan permainan tenis lapangan pada siswa SD kelas atas dalam pembelajaran Penjasorkes khususnya untuk materi permainan bola kecil.

Media pembelajaran yang dikembangkan ini memiliki ciri khas dalam hal materi, dimana materi-materi yang diberikan yaitu penyederhanaan dari materi permainan tenis yang sesungguhnya, sehingga siswa dapat dengan mudah mengikuti dan melakukan teknik gerak dasar permainan tenis lapangan. Tanpa disuruh ataupun diminta oleh guru dengan sadar siswa pun berlatih sendiri saat waktu luang ataupun istirahat.

\section{Saran}

Produk media VCD pembelajaran "permainan tenis lapangan untuk siswa sekolah dasar kelas atas" ini hendaknya dapat disosialisasikan lebih luas oleh guru-guru Penjasorkes, sehingga penggunaaan media pembelajaran ini dapat menjadi alternatif bagi pembelajaran Penjasorkes pada materi permainan bola kecil, dan mampu membantu dalam penyampaian materi pembelajaran. Penelitian media pembelajaran VCD ini hendaknya suatu saat bisa dikembang- kan kembali dengan melengkapi gerak dasar lain yang belum tersampaikan dalam media pembelajaran ini, agar dapat melengkapi media VCD pembelajaran ini.

\section{Daftar Pustaka}

Bompa, Tudor O. (1999). Theory and methodology of training. the key to athletic performance, $4^{\text {rd }}$ Edition. Dubuque, Iowa: Kendall/Hunt Publishing Company.

Curtner-Smith, Matthew D. (1996). Using games invention with elementary children. Journal of Physical Education, Recreation \& Dance.; 67, 3; ProQuest. pg. 33. http://proquest.umi.com/pqdweb

Middleton, David (2004). Playing tennis without a net. The South Carolina Review. ProQuest Research Library. pg. 201 http://proquest.umi.com/pqdweb.

Sukadiyanto (1999). Tenis mini: Metode pembelajaran menuju permainan tenis. Majora. Vol 5, No.2. Yogyakarta: FIK UNY.

(2003). Keterampilan groundstrokes petenis pemula. Disertasi: tidak dipublikasikan. Jakarta. Universitas Negeri Jakarta. 